\title{
Citreimonas salinaria gen. nov., sp. nov., a member of the Roseobacter clade isolated from a solar saltern
}

\author{
Dong H. Choit and Byung C. Cho
}

Correspondence

Byung C. Cho

bccho@snu.ac.kr
School of Earth and Environmental Sciences and Research Institute of Oceanography, Seoul National University, 56-1 Shillim-dong, Kwanak-gu, Seoul 151-742, Republic of Korea
Since the description of the genus Roseobacter within the $\alpha-3$ subgroup of the Proteobacteria (Shiba, 1991), many strains have been isolated, mainly from various marine environments (e.g. seawater, sediment, marine algae and invertebrates, vertebrates, hypersaline microbial mats and coastal biofilms), and the Roseobacter clade is now known to be one of the most abundant groups present in marine environments (Giovannoni \& Rappé, 2000; Selje et al., 2004; Buchan et al., 2005). In addition, the Roseobacter clade constitutes a numerically important heterotrophic bacterial group present in hypersaline microbial mats (Jonkers \& Abed, 2003). Species isolated from hypersaline environments include Antarctobacter heliothermus, Roseisalinus antarcticus, Roseovarius tolerans, Staleya guttiformis and Sulfitobacter brevis from the hypersaline Ekho Lake (Labrenz et al., 1998, 1999, 2000, 2005), Roseivivax halodurans and Roseivivax halotolerans from a saline lake in Western Australia (Suzuki et al., 1999), Palleronia marisminoris and Salipiger mucosus from hypersaline soil (Martínez-Cánovas et al., 2004, Martínez-Checa et al., 2005) and Jannaschia seosinensis

†Present address: Marine Environmental Research Department, Korea Ocean Research and Development Institute, Ansan 426-744, Republic of Korea.

The GenBank/EMBL/DDBJ accession number for the 16S rRNA gene sequence of strain CL-SP2O ${ }^{\top}$ is AY962295. from hypersaline water from a solar saltern (Choi et al., 2006a).

Strain CL-SP20 ${ }^{\mathrm{T}}$, which is affiliated with the Rhodobacteraceae, was isolated from hypersaline water $(31 \cdot 8 \%$ salinity) from a solar saltern in Seosin, Korea. The water was spread on marine agar 2216 (MA; Difco) and incubated at $30{ }^{\circ} \mathrm{C}$ for 2 weeks. Strain CL-SP $20^{\mathrm{T}}$ was isolated and subsequently purified four times on $\mathrm{MA}$ at $30^{\circ} \mathrm{C}$. The strain was maintained both on MA at $4{ }^{\circ} \mathrm{C}$ and at $-80^{\circ} \mathrm{C}$ in marine broth (MB; Difco) supplemented with $30 \%(\mathrm{v} / \mathrm{v})$ glycerol.

The 16S rRNA gene was amplified from a single colony by using a PCR with Taq DNA polymerase (Bioneer) and primers 27F and 1492R (Lane, 1991). The PCR product was purified using the AccuPrep PCR purification kit (Bioneer) and cloned using the pCR2.1 TOPO TA cloning kit (Invitrogen). Sequencing of the 16S rRNA gene was performed with an Applied Biosystems automatic sequencer (ABI3730XL) at Macrogen Corp. (Seoul, Korea). The almost-complete $16 \mathrm{~S}$ rRNA gene sequence of strain CL$\mathrm{SP} 20^{\mathrm{T}}$ (1401 bp) was obtained and then compared, using BLASTN searches (Altschul et al., 1990), with 16S rRNA gene sequences available in GenBank. The sequence of strain CL-SP $20^{\mathrm{T}}$ was manually aligned with those of species from the Roseobacter clade, obtained from the GenBank and Ribosomal Database Project (Cole et al., 2003) databases, 
using known 16S rRNA secondary-structure information. Phylogenetic trees were obtained by using neighbourjoining (Saitou \& Nei, 1987), maximum-parsimony (Fitch, 1971) and maximum-likelihood (Felsenstein, 1981) methods. An evolutionary distance matrix for the neighbourjoining method was generated according to the model of Jukes \& Cantor (1969). The robustness of the tree topologies was assessed using bootstrap analyses based on 1000 replications for the neighbour-joining and maximumparsimony methods and 100 replications for the maximum-likelihood method. Alignment analysis was carried out using the jPHYDIT program (Jeon et al., 2005), and phylogenetic analyses were carried out using MEGA3 (Kumar et al., 2004) and PAUP* 4.0 (Swofford, 1998). Likelihood parameters were estimated by the hierarchical ratio tests in MODELTEST 3.04 (Posada \& Crandall, 1998).

Morphological and physiological analyses were performed as follows. Gram-staining was performed as described by Smibert \& Krieg (1994). Cell morphology and motility were examined by phase-contrast microscopy and transmission electron microscopy (EX2; JEOL) with cells grown for 2 days in $\mathrm{MB}$ at $30^{\circ} \mathrm{C}$. Anaerobic growth was checked on $\mathrm{MA}$ using the GasPak anaerobic system (BBL). Bacteriochlorophyll $a$ production was determined in $90 \%$ acetone extracts from cells cultured in the dark, and examined with a spectrophotometer (Ultraspec 2000; Pharmacia Biotech). The temperature range for growth was determined on the basis of colony formation on MA plates incubated at temperatures ranging from 5 to $45^{\circ} \mathrm{C}$ (in increments of $5^{\circ} \mathrm{C}$ ). The $\mathrm{pH}$ range (tested at $\mathrm{pH} 5-11$ in increments of $1 \mathrm{pH}$ unit) for growth was determined, in $\mathrm{MB}$, by changes in the $\mathrm{OD}_{600}$ over time. The final $\mathrm{pH}$ was adjusted using $\mathrm{NaOH}$ and $\mathrm{HCl}$ solutions. The tolerance of CL-SP $20^{\mathrm{T}}$ to sea salts was determined using synthetic ZoBell broth (Bacto peptone, $5 \mathrm{~g}$; yeast extract, $1 \mathrm{~g}$; ferric citrate, $0.1 \mathrm{~g}$; distilled water, $1 \mathrm{l}$ ) with various concentrations $(0-10 \%$, in increments of $1 \%$, and at 15,20 and $25 \%$, w/v) of sea salts (Sigma). Growth in a medium containing $\mathrm{NaCl}$ as the sole salt was tested in a synthetic ZoBell agar medium supplemented with $3 \% \mathrm{NaCl}$. Catalase and oxidase activities were determined according to the protocols described by Smibert \& Krieg (1994), and gelatinase, amylase, DNase and nitrate reductase activities and degradation of Tween 80 were examined as described by Hansen \& Sørheim (1991). In addition, nitrate reduction, the production of indole, arginine dihydrolase, urease, gelatinase and $\beta$-galactosidase activities, acid production from glucose and the hydrolysis of aesculin were tested using an API 20NE kit (bioMérieux) according to the manufacturer's instructions, except that the cell suspension was prepared using artificial seawater ( $\mathrm{NaCl}, 24 \mathrm{~g} ; \mathrm{MgCl}_{2}, 5 \cdot 1 \mathrm{~g} ; \mathrm{Na}_{2} \mathrm{SO}_{4}, 4 \mathrm{~g} ; \mathrm{CaCl}_{2}, 1 \cdot 1 \mathrm{~g} ; \mathrm{KCl}$, $0.7 \mathrm{~g} ; \mathrm{NaHCO}_{3}, 0.2 \mathrm{~g} ; \mathrm{KBr}, 0.1 \mathrm{~g} ; \mathrm{H}_{3} \mathrm{BO}_{3}, 0.027 \mathrm{~g}$; $\mathrm{SrCl}_{2}, 0.024 \mathrm{~g}$; NaF, 0.003 g; distilled water, 1 l) (Lyman \& Fleming, 1940). Other enzyme activities were assayed using the API ZYM kit (bioMérieux) and artificial seawater as the suspension medium. Carbon utilization was tested on basal agar medium supplemented with yeast extract $(\mathrm{NaCl}$,
$23.6 \mathrm{~g} ; \mathrm{KCl}, 0.64 \mathrm{~g}, \mathrm{MgCl}_{2} \cdot 6 \mathrm{H}_{2} \mathrm{O}, 4.53 \mathrm{~g} ; \mathrm{MgSO}_{4} .7 \mathrm{H}_{2} \mathrm{O}$, $5.94 \mathrm{~g} ; \mathrm{CaCl}_{2} .2 \mathrm{H}_{2} \mathrm{O}, 1.3 \mathrm{~g} ; \mathrm{NaNO}_{3}, 0.2 \mathrm{~g} ; \mathrm{NH}_{4} \mathrm{Cl}, 0.2 \mathrm{~g}$; Bacto agar, $15 \mathrm{~g}$; yeast extract, $0.05 \mathrm{~g}$; distilled water, $1 \mathrm{l}$ ) (Choi et al., 2006b) containing $0 \cdot 4 \%$ carbon source. Incubation was performed for 1 month and growth was scored as negative when it was equal to, or less than, that in the negative control (lacking any carbon source). The ability to oxidize thiosulfate was tested on solid medium, according to protocols modified from those described by González et al. (1999). Strain CL-SP $20^{\mathrm{T}}$ was streaked on medium supplemented with thiosulfate (HEPES, $10 \mathrm{~g} ; \mathrm{NaCl}, 20 \mathrm{~g}$; $\mathrm{K}_{2} \mathrm{HPO}_{4}, 0.5 \mathrm{~g} ; \mathrm{NH}_{4} \mathrm{Cl}, 0.5 \mathrm{~g} ; \mathrm{MgSO}_{4} .7 \mathrm{H}_{2} \mathrm{O}, 0.6 \mathrm{~g}$; $\mathrm{CaCl}_{2} \cdot 2 \mathrm{H}_{2} \mathrm{O}, 0.3 \mathrm{~g}$; sodium acetate, $20 \mathrm{mM}$; sodium thiosulfate, $20 \mathrm{mM}$; yeast extract, $0.05 \mathrm{~g}$; agar, $15 \mathrm{~g}$; distilled water, 11 ); negative controls were prepared with the same medium but without sodium thiosulfate. After 2 weeks incubation, the results were read according to González et al. (1999). All phenotypic assays (except analysis of the temperature range) were carried out at $30^{\circ} \mathrm{C}$.

The fatty acid methyl esters in whole cells were analysed by gas chromatography according to the instructions of the Microbial Identification System (MIDI) at the Korean Culture Center of Microorganisms (Seoul, Korea). The DNA G $+\mathrm{C}$ content was determined by HPLC analysis of deoxyribonucleosides as described by Mesbah et al. (1989) after DNA purification by the method of Marmur (1961).

The 16S rRNA gene sequence of CL-SP20 ${ }^{\mathrm{T}}$ showed $96 \cdot 3 \%$ sequence similarity to Citreicella thiooxidans CHLG $1^{\mathrm{T}}$, $95 \cdot 3 \%$ to Roseivivax halodurans OCh $239^{\mathrm{T}}, 94 \cdot 9 \%$ to Roseivivax halotolerans OCh $210^{\mathrm{T}}$ and $91 \cdot 0-94 \cdot 9 \%$ to other species of the Roseobacter lineage. In spite of a high level of sequence similarity between strain CL-SP2 $2{ }^{\mathrm{T}}$ and Citreicella thiooxidans, strain CL-SP20 ${ }^{\mathrm{T}}$ did not form a robust clade with Citreicella thiooxidans or any other species in the Roseobacter lineage, but instead formed a distinct subline in all 16S rRNA gene sequence-based phylogenetic trees constructed using different methods (Fig. 1). Thus, strain CL-SP $20^{\mathrm{T}}$ could be recognized as representing a distinct genus.

The cells of strain CL-SP $20^{\mathrm{T}}$ were non-motile, ovoid rods, $0.5-0.8 \mu \mathrm{m}$ in width and $1.0-1.5 \mu \mathrm{m}$ in length in the exponential growth phase, and occasionally formed short chains (Fig. 2). Bright inclusions inside the cells were not observed under phase-contrast microscopy, but poly- $\beta$ hydroxybutyrate granules were identified by staining with Nile blue A (Ostle \& Holt, 1982). Colonies on MA were circular, entire, convex, opaque, shiny and beige in colour. After incubation for 1 week, colonies were approximately $1 \mathrm{~mm}$ in diameter. Bacteriochlorophyll $a$ was not detected. Growth of CL-SP $20^{\mathrm{T}}$ was observed at temperatures from 15 to $40{ }^{\circ} \mathrm{C}$, with an optimum between 30 and $35^{\circ} \mathrm{C}$. Growth occurred at $\mathrm{pH} 6-10$, with an optimum at $\mathrm{pH} 7-8$. Strain CL-SP20 $0^{\mathrm{T}}$ grew with sea salts at concentrations from 1 to $10 \%$ (with an optimum between 5 and $6 \%$ ), but did not grow on agar plates containing $3 \% \mathrm{NaCl}$ as the sole source of salt. Strain CL-SP20 ${ }^{\mathrm{T}}$ degraded DNA and gelatin and 


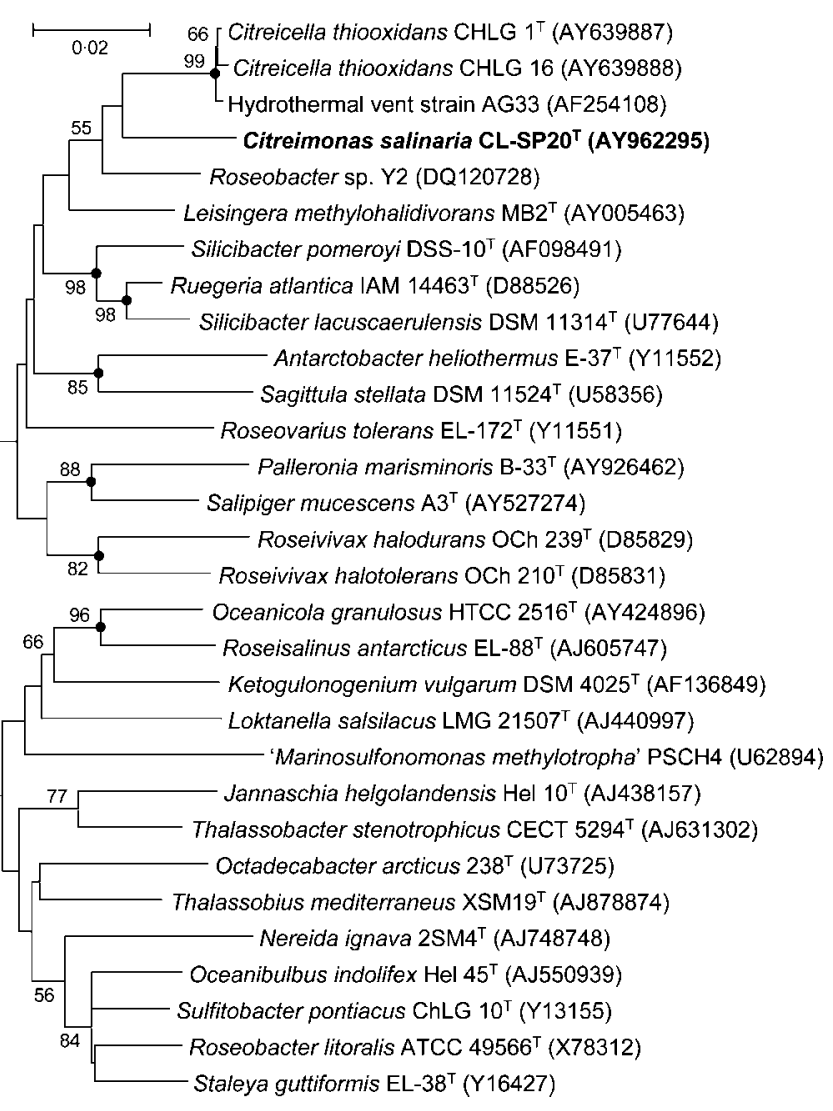

Fig. 1. Neighbour-joining phylogenetic tree, based on $16 \mathrm{~S}$ rRNA gene sequences, showing the relationships between strain CL-SP20 ${ }^{\top}$ and related species belonging to the Roseobacter clade of the family Rhodobacteraceae. Only bootstrap values above $50 \%$ are shown (1000 resamplings) at the branching points. Filled circles indicate that the corresponding nodes were also recovered in the maximum-parsimony and maximum-likelihood trees. Escherichia coli ATCC $11775^{\top}$ (GenBank accession no. X80725) was used as an outgroup (not shown). Bar, 0.02 nucleotide substitutions per site.

reduced nitrate to nitrite, but did not degrade starch. It was positive for catalase, aesculin hydrolysis, alkaline phosphatase, esterase lipase and valine arylamidase, but was negative for cytochrome oxidase, urease, acid phosphatase and $\alpha$ glucosidase (Table 1). Strain CL-SP20 ${ }^{\mathrm{T}}$ was unable to oxidize thiosulfate. The other results of biochemical and physiological tests are given in Table 1 and the species description.

The predominant fatty acid in CL-SP2 $0^{\mathrm{T}}$ was $18: 1 \omega 7 c$ $(54.3 \%$ ) (a feature shared by members of the Roseobacter clade); this was followed by $19: 0$ cyclo $\omega 8 c(20 \cdot 4 \%)$, $18: 3 \omega 6 c(6,9,12)(7 \cdot 7 \%)$, 11-methyl $18: 1 \omega 7 c(5 \cdot 5 \%)$, $16: 0(5 \cdot 3 \%), 18: 0(4 \cdot 0 \%)$ and $12: 13-\mathrm{OH}(2 \cdot 9 \%)$ (Table 1 ). The DNA G $+\mathrm{C}$ content was $67 \cdot 3 \mathrm{~mol} \%$.

Strain CL-SP20 $0^{\mathrm{T}}$ is closely related to Citreicella thiooxidans on the basis of $16 \mathrm{~S}$ rRNA gene sequence similarity. However,

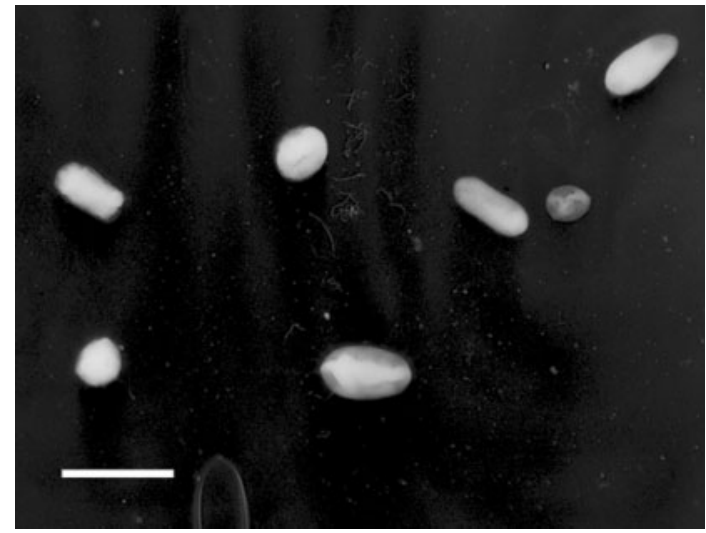

Fig. 2. Transmission electron micrograph of negatively stained cells of strain CL-SP20 ${ }^{\top}$. Bar, $2 \mu \mathrm{m}$.

the phylogenetic analysis showed that CL-SP20 ${ }^{\mathrm{T}}$ does not form a robust clade with Citreicella thiooxidans strains; furthermore, CL-SP2 $20^{\mathrm{T}}$ can be differentiated from this most closely related micro-organism by its inability to oxidize thiosulfate, its ability to reduce nitrate, its gelatinase activity, the absence of oxidase, urease, acid phosphatase and $\alpha$ glucosidase, its carbon-utilization characteristics and its responses to temperature and sea salts (Table 1 ). The fatty acid profile of strain CL-SP $20^{\mathrm{T}}$ is also obviously different from that of Citreicella thiooxidans, i.e. in the proportions of the major fatty acids $(18: 1 \omega 7 c$ and 19:0 cyclo $\omega 8 c)$ and by the presence or absence of other fatty acids (Table 1). Overall, the polyphasic taxonomic evidence based on phylogenetic analysis of $16 \mathrm{~S}$ rRNA gene sequences, fatty acid profiles and phenotypic features indicate that strain CL$\mathrm{SP} 20^{\mathrm{T}}$ should be classified within a novel genus and species, for which the name Citreimonas salinaria gen. nov., sp. nov. is proposed.

\section{Description of Citreimonas gen. nov.}

Citreimonas (Cit.re.i.mo' nas. L. n. citreum lemon; L. fem. n. monas a unit, monad; N.L. fem. n. Citreimonas a lemonshaped monad).

Cells are Gram-negative, lemon-shaped rods. Obligately heterotrophic and aerobic. Catalase-positive and oxidasenegative. The predominant fatty acids are $18: 1 \omega 7 c$ and 19: 0 cyclo $\omega 8 c$. Cells do not contain bacteriochlorophyll $a$ and do not oxidize thiosulfate. The genus is a member of the family Rhodobacteraceae. The type species is Citreimonas salinaria.

\section{Description of Citreimonas salinaria sp. nov.}

Citreimonas salinaria (sa.li.na' ri.a. L. fem. adj. salinaria of or belonging to a salt-works).

Shows the following properties in addition to those in the genus description. Cells are non-motile and approximately $0 \cdot 5-0 \cdot 8 \mu \mathrm{m}$ wide and $1 \cdot 0-1 \cdot 5 \mu \mathrm{m}$ long. On MA medium, 
Table 1. Major characteristics that differentiate strain CL$\mathrm{SP} 20^{\top}$ from the phylogenetically related micro-organism Citreicella thiooxidans

Taxa: 1, strain CL-SP20 ${ }^{\mathrm{T}} ; 2$, Citreicella thiooxidans (Sorokin et al., 2005). +, Positive; -, negative; W, weakly positive; ND, not detected. Data for the sea-salts ranges, API 20NE and API ZYM tests and fatty acids were obtained in this study.

\begin{tabular}{|c|c|c|}
\hline Characteristic & 1 & 2 \\
\hline Origin & Solar saltern & Black Sea \\
\hline $\begin{array}{l}\text { Temperature range }\left({ }^{\circ} \mathrm{C}\right) \\
\text { (optimum) }\end{array}$ & $15-40(30-35)$ & $8-35(25-28)$ \\
\hline Sea-salts range (\%) (optimum) & $1-10(5-6)$ & $0 \cdot 5-15(2-5)$ \\
\hline DNA G + C content $(\mathrm{mol} \%)$ & $67 \cdot 3$ & $67 \cdot 5-69 \cdot 2$ \\
\hline Oxidase activity & - & + \\
\hline Thiosulfate oxidation & - & + \\
\hline \multicolumn{3}{|l|}{ API 20NE tests } \\
\hline Nitrate reduction & $+^{*}$ & - \\
\hline Urease & - & + \\
\hline Aesculin hydrolysis & + & $\mathrm{W}$ \\
\hline Gelatinase & $+^{*}$ & - \\
\hline \multicolumn{3}{|l|}{ API ZYM tests } \\
\hline Alkaline phosphatase & $\mathrm{W}$ & + \\
\hline Esterase lipase (C8) & + & - \\
\hline Valine arylamidase & $\mathrm{W}$ & - \\
\hline Acid phosphatase & - & + \\
\hline$\alpha$-Glucosidase & - & $\mathrm{W}$ \\
\hline \multicolumn{3}{|l|}{ Fatty acids ( $\%$ of total) } \\
\hline $12: 03-\mathrm{OH}$ & $\mathrm{ND}$ & $3 \cdot 1$ \\
\hline $12: 13-\mathrm{OH}$ & $2 \cdot 9$ & $0 \cdot 3$ \\
\hline $16: 0$ & $5 \cdot 3$ & $7 \cdot 7$ \\
\hline $17: 1 \omega 8 c$ & $\mathrm{ND}$ & $1 \cdot 0$ \\
\hline $18: 0$ & $4 \cdot 0$ & $0 \cdot 5$ \\
\hline $18: 3 \omega 6 c(6,9,12)$ & $7 \cdot 7$ & $\mathrm{ND}$ \\
\hline $18: 1 \omega 7 c$ & $54 \cdot 3$ & $77 \cdot 4$ \\
\hline 11-Methyl $18: 1 \omega 7 c$ & $5 \cdot 5$ & $0 \cdot 6$ \\
\hline $19: 0$ cyclo $\omega 8 c$ & $20 \cdot 4$ & $4 \cdot 5$ \\
\hline ECL $15 \cdot 818 \dagger$ & ND & $2 \cdot 0$ \\
\hline \multicolumn{3}{|l|}{ Utilization of: } \\
\hline Ethanol & - & + \\
\hline D-Mannitol & - & + \\
\hline Sorbitol & - & + \\
\hline L-Aspartate & - & + \\
\hline L-Asparagine & - & + \\
\hline L-Glutamate & - & + \\
\hline
\end{tabular}

*Test was also performed according to Hansen \& Sørheim (1991) and gave a congruent result.

$\dagger \mathrm{ECL}$, Equivalent chain-length; represents 15:0 iso 2-OH and/or $16: 1 \omega 7 c$.

colonies are circular with an entire margin, convex, opaque, shiny and beige in colour. Grows at temperatures in the range $15-40{ }^{\circ} \mathrm{C}$ (optimum, $30-35^{\circ} \mathrm{C}$ ) and at $\mathrm{pH} 6-10$. Growth occurs at sea salts concentrations of $1-10 \%(\mathrm{w} / \mathrm{v})$. No growth occurs without sea salts in the medium. DNase, gelatinase, nitrate reductase, esterase, esterase lipase and leucine arylamidase activities are present and alkaline phosphatase and valine arylamidase activities are weakly present. Amylase, indole production, acid production from glucose, arginine dihydrolase, urease, $\beta$-galactosidase, Tween 80 degradation, lipase, cystine arylamidase, trypsin, $\alpha$-chymotrypsin, acid phosphatase, naphtholAS-BI-phosphohydrolase, $\alpha$-galactosidase, $\beta$-galactosidase, $\beta$-glucuronidase, $\alpha$-glucosidase, $\beta$-glucosidase, $N$-acetyl $\beta$ glucosaminidase, $\alpha$-mannosidase and $\alpha$-fucosidase activities are absent. Growth occurs on L-arabinose, cellobiose, Dfructose, D-glucose, D-mannose, sucrose, D-trehalose, Dxylose, acetone, acetate, Casamino acids, pyruvate, citrate, succinate, glycerol, $\mathrm{N}$-acetylglucosamine, inulin, salicin, Larginine, L-leucine, L-lysine, L-ornithine and L-proline. No growth occurs on $\alpha$-ketobutyric acid, acetamide, Dgalactose, D-raffinose, D-ribose, L-rhamnose, polyethylene glycol, ascorbate, benzoate, formic acid, lactose, maleic acid, salicylate, tartrate, ethanol, myo-inositol, 2-propanol, Dmannitol, sorbitol, L-aspartate, L-asparagine, DL-cysteine, Lglutamate, glycine, glycogen, thiamine or urea. The DNA $\mathrm{G}+\mathrm{C}$ content is $67 \cdot 3 \mathrm{~mol} \%$.

The type strain, CL-SP $20^{\mathrm{T}} \quad\left(=\mathrm{KCCM} \quad 42116^{\mathrm{T}}=\mathrm{JCM}\right.$ $13036^{\mathrm{T}}$ ), was isolated from hypersaline water from a solar saltern in Seosin, Korea.

\section{Acknowledgements}

This work was supported, in part, by the Korea Sea Grant Program (to B. C. C.) and by the BK21 project of the Korean Government.

\section{References}

Altschul, S. F., Gish, W., Miller, W., Myers, E. W. \& Lipman, D. J. (1990). Basic local alignment search tool. J Mol Biol 215, 403-410.

Buchan, A., González, J. M. \& Moran, M. A. (2005). Overview of the marine Roseobacter lineage. Appl Environ Microbiol 71, 5665-5677.

Choi, D. H., Yi, H., Chun, J. \& Cho, B. C. (2006a). Jannaschia seosinensis sp. nov., isolated from hypersaline water of a solar saltern in Korea. Int J Syst Evol Microbiol 56, 45-49.

Choi, D. H., Kim, Y. G., Hwang, C. Y., Yi, H., Chun, J. \& Cho, B. C. (2006b). Tenacibaculum litoreum sp. nov., isolated from tidal flat sediment. Int J Syst Evol Microbiol 56, 635-640.

Cole, J. R., Chai, B., Marsh, T. L. \& 8 other authors (2003). The Ribosomal Database Project (RDP-II): previewing a new autoaligner that allows regular updates and the new prokaryotic taxonomy. Nucleic Acids Res 31, 442-443.

Felsenstein, J. (1981). Evolutionary trees from DNA sequences: a maximum likelihood approach. J Mol Evol 17, 368-376.

Fitch, W. M. (1971). Toward defining the course of evolution: minimum change for a specific tree topology. Syst Zool 20, 406-416.

Giovannoni, S. J. \& Rappé, M. (2000). Evolution, diversity and molecular ecology of marine prokaryotes. In Microbial Ecology of the Oceans, pp. 47-84. Edited by D. L. Kirchman. New York: Wiley.

González, J. M., Kiene, R. P. \& Moran, M. (1999). Transformation of sulfur compounds by an abundant lineage of marine bacteria in the $\alpha$-subclass of the class Proteobacteria. Appl Environ Microbiol 65, $3810-3819$ 
Hansen, G. H. \& Sørheim, R. (1991). Improved method for phenotypical characterization of marine bacteria. J Microbiol Methods 13, 231-241.

Jeon, Y.-S., Chung, H., Park, S., Hur, I., Lee, J.-H. \& Chun, J. (2005). jPHYDIT: a JAVA-based integrated environment for molecular phylogeny of ribosomal RNA sequences. Bioinformatics 21, 3171-3173.

Jonkers, H. M. \& Abed, R. M. M. (2003). Identification of aerobic heterotrophic bacteria from the photic zone of a hypersaline microbial mat. Aquat Microb Ecol 30, 127-133.

Jukes, T. H. \& Cantor, C. R. (1969). Evolution of protein molecules. In Mammalian Protein Metabolism, pp. 21-132. Edited by H. N. Munro. New York: Academic Press.

Kumar, S., Tamura, K. \& Nei, M. (2004). MEGA3: integrated software for molecular evolutionary genetics analysis and sequence alignment. Brief Bioinform 5, 150-163.

Labrenz, M., Collins, M. D., Lawson, P. A., Tindall, B. J., Braker, G. \& Hirsch, P. (1998). Antarctobacter heliothermus gen. nov., sp. nov., a budding bacterium from hypersaline and heliothermal Ekho Lake. Int J Syst Bacteriol 48, 1363-1372.

Labrenz, M., Collins, M. D., Lawson, P. A., Tindall, B. J., Schumann, P. \& Hirsch, P. (1999). Roseovarius tolerans gen. nov., sp. nov., a budding bacterium with variable bacteriochlorophyll a production from hypersaline Ekho Lake. Int J Syst Bacteriol 49, 137-147.

Labrenz, M., Tindall, B. J., Lawson, P. A., Collins, M. D., Schumann, P. \& Hirsch, P. (2000). Staleya guttiformis gen. nov., sp. nov., and Sulfitobacter brevis sp. nov., $\alpha$-3-Proteobacteria from hypersaline, heliothermal and meromictic Antarctic Ekho Lake. Int J Syst Evol Microbiol 50, 303-313.

Labrenz, M., Lawson, P. A., Tindall, B. J., Collins, M. D. \& Hirsch, P. (2005). Roseisalinus antarcticus gen. nov., sp. nov., a novel aerobic bacteriochlorophyll $a$-producing $\alpha$-proteobacterium isolated from hypersaline Ekho Lake, Antarctica. Int J Syst Evol Microbiol 55, 41-47.

Lane, D. J. (1991). 16S/23S rRNA sequencing. In Nucleic Acid Techniques in Bacterial Systematics, pp. 115-175. Edited by E. Stackebrandt \& M. Goodfellow. Chichester: Wiley.

Lyman, J. \& Fleming, R. H. (1940). Composition of sea water. J Mar Res 3, 134-146.

Marmur, J. (1961). A procedure for the isolation of deoxyribonucleic acid from microorganisms. J Mol Biol 3, 208-218.
Martínez-Cánovas, M. J., Quesada, E., Martínez-Checa, F., del Moral, A. \& Béjar, V. (2004). Salipiger mucescens gen. nov., sp. nov., a moderately halophilic, exopolysaccharide-producing bacterium isolated from hypersaline soil, belonging to the $\alpha$-Proteobacteria. Int J Syst Evol Microbiol 54, 1735-1740.

Martínez-Checa, F., Quesada, E., Martínez-Cánovas, M. J., Llamas, I. \& Béjar, V. (2005). Palleronia marisminoris gen. nov., sp. nov., a moderately halophilic, exopolysaccharide-producing bacterium belonging to the 'Alphaproteobacteria', isolated from a saline soil. Int J Syst Evol Microbiol 55, 2525-2530.

Mesbah, M., Premachandran, U. \& Whitman, W. B. (1989). Precise measurement of the $\mathrm{G}+\mathrm{C}$ content of deoxyribonucleic acid by highperformance liquid chromatography. Int J Syst Bacteriol 39, 159-167.

Ostle, A. G. \& Holt, J. G. (1982). Nile blue A as fluorescent stain for poly- $\beta$-hydroxybutyrate. Appl Environ Microbiol 44, 238-241.

Posada, D. \& Crandall, K. A. (1998). MODELTEST: testing the model of DNA substitution. Bioinformatics 14, 817-818.

Saitou, N. \& Nei, M. (1987). The neighbor-joining method: a new method for reconstructing phylogenetic trees. Mol Biol Evol 4, 406-425.

Selje, N., Simon, M. \& Brinkhoff, T. (2004). A newly discovered Roseobacter cluster in temperate and polar oceans. Nature 427, 445-448.

Shiba, T. (1991). Roseobacter litoralis gen. nov., sp. nov., and Roseobacter denitrificans sp. nov., aerobic pink-pigmented bacteria which contain bacteriochlorophyll a. Syst Appl Microbiol 14, 140-145.

Smibert, R. M. \& Krieg, N. R. (1994). Phenotypic characterization. In Methods for General and Molecular Bacteriology, pp. 607-654. Edited by P. Gerhardt, R. G. E. Murray, W. A. Wood \& N. R. Krieg. Washington, DC: American Society for Microbiology.

Sorokin, D. Y., Tourova, T. P. \& Muyzer, G. (2005). Citreicella thiooxidans gen. nov., sp. nov., a novel lithoheterotrophic sulfuroxidizing bacterium from the Black Sea. Syst Appl Microbiol 28, 679-687.

Suzuki, T., Muroga, Y., Takahama, M. \& Nishimura, Y. (1999). Roseivivax halodurans gen. nov., sp. nov., and Roseivivax halotolerans sp. nov., aerobic bacteriochlorophyll-containing bacteria isolated from a saline lake. Int J Syst Bacteriol 49, 629-634.

Swofford, D. L. (1998). PAUP ${ }^{*}$ - phylogenetic analysis using parsimony and other methods, version 4. Sunderland, MA: Sinauer Associates. 